\title{
Birth and Death of Human $\beta$-Cells in Pancreases From Cadaver Donors, Autopsies, Surgical Specimens, and Islets Transplanted Into Mice
}

\author{
Francisco Caballero,* Karolina Siniakowicz,* Jennifer-Hollister-Lock,* Luisa Duran,* \\ Hitoshi Katsuta,* Takatsugu Yamada,* Ji Lei, $†$ Shaoping Deng, $\dagger$ Gunilla T. Westermark, \\ James Markmann, $\dagger$ Susan Bonner-Weir,* and Gordon C. Weir*
}

*Section on Islet Cell and Regenerative Biology, Research Division, Joslin Diabetes Center, Boston, MA, USA $\dagger$ Division of Transplantation, Department of Surgery, Massachusetts General Hospital, Harvard Medical School, Boston, MA, USA †Department of Medical Cell Biology, Uppsala University, Uppsala, Sweden

\begin{abstract}
There is great interest in the potential of the human endocrine pancreas for regeneration by $\beta$-cell replication or neogenesis. Our aim was to explore this potential in adult human pancreases and in both islet and exocrine tissue transplanted into mice. The design was to examine pancreases obtained from cadaver donors, autopsies, and fresh surgical specimens and compare these findings with those obtained from islet and duct tissue grafted into the kidney. Islets and exocrine tissue were transplanted into normoglycemic ICR-SCID mice and studied 4 and 14 weeks later. $\beta$-Cell replication, as assessed by double staining for insulin and Ki67, was $0.22 \pm 0.03 \%$ at 4 weeks and $0.13 \pm 0.03 \%$ at 14 weeks. In contrast, no evidence of $\beta$-cell replication could be found in 11 cadaver donor and 10 autopsy pancreases. However, Ki67 staining of $\beta$-cells in frozen sections obtained at surgery was comparable to that found in transplanted islets. Evidence for neogenesis in transplanted pancreatic exocrine tissue was supported by finding $\beta$-cells within the duct epithelium and the presence of cells double stained for insulin and cytokeratin 19 (CK19). However, $\beta$-cells within the ducts never constituted more than $1 \%$ of the CK19-positive cells. With confocal microscopy, 7 of 12 examined cells expressed both markers, consistent with a neogeneic process. Mice with grafts containing islet or exocrine tissue were treated with various combinations of exendin-4, gastrin, and epidermal growth factor; none increased $\beta$-cell replication or stimulated neogenesis. In summary, human $\beta$-cells replicate at a low level in islets transplanted into mice and in surgical pancreatic frozen sections, but rarely in cadaver donor or autopsy pancreases. The absence of $\beta$-cell replication in many adult cadaver or autopsy pancreases could, in part, be an artifact of the postmortem state. Thus, it appears that adult human $\beta$-cells maintain a low level of turnover through replication and neogenesis.
\end{abstract}

Key words: Diabetes; Turnover; $\beta$-Cell neogenesis; $\beta$-Cell replication

\section{INTRODUCTION}

$\beta$-Cell deficiency is fundamental to the pathogenesis of both type 1 and type 2 diabetes. In type 1 diabetes $\beta$-cells are decimated by autoimmunity, and in type 2 diabetes $\beta$-cell mass is reduced by $40-60 \%$ (4), but normoglycemia can be restored in both by $\beta$-cell transplantation. This important proof of principle has been most clearly shown with islet transplantation (24) and for type 2 diabetes with pancreas transplantation (15). The major obstacles preventing widespread clinical application are in controlling immune destruction and finding an adequate supply of $\beta$-cells.

Impressive progress has been made in directing human embryonic stem cells to mature functional $\beta$-cells (12). Considerable attention has also been focused on determining the capacity of the adult human pancreas for $\beta$-cell regeneration either by stimulating $\beta$-cell replication or by forming new $\beta$-cells from a precursor population through neogenesis. In rodents, $\beta$-cell replication can be active enough for substantial regeneration (16), and neogenesis from duct precursor cells has the potential to generate new islets (1). In humans, $\beta$-cell replication in most adult pancreas appears to be negligible $(4,6,8,17)$, and there is evidence for some neogenesis $(1,3)$. A major question is whether meaningful regeneration of $\beta$-cells can be stimulated in human pancreas. This is a particularly important issue because agents, such as glucagon-like peptide-1 (GLP-1) receptor agonists, gastrin, epidermal growth factor (EGF), and islet neogenesisassociated peptide (INGAP), used as single agents or in combination, have been shown to stimulate regeneration in rodents (1). Unfortunately, it is not possible to measure $\beta$-cell mass in the pancreas of living human

Received December 9, 2011; final acceptance November 29, 2012. Online prepub date: January 2, 2013.

Address correspondence to Gordon C. Weir, M.D., Section on Islet Cell and Regenerative Biology, Joslin Diabetes Center, One Joslin Place, Boston, MA 02215, USA. Tel: +1-617-309-2581; Fax: +1-617-309-2650; E-mail: gordon.weir@ joslin.harvard.edu 
Table 1. Sources of Pancreatic Tissue Used for Study

\begin{tabular}{lccc}
\hline Pancreas Tissue Source & $\begin{array}{c}\text { Subject } \\
\text { Numbers }\end{array}$ & Use & Tissue Preparation and Immunostaining \\
\hline Cadaver organ donors & 13 & $\begin{array}{c}\text { Islets and exocrine tissue } \\
\text { transplantation into mice }\end{array}$ & $\begin{array}{l}\text { Removal of kidney-PFA and paraffin } \\
\text { Staining for insulin, glucagon, } \\
\text { cytokeratin, Ki67, and BrdU } \\
\text { PFA and paraffin } \\
\text { Staining for insulin, glucagon, Ki67, } \\
\text { and BrdU }\end{array}$ \\
Cadaver organ donors & 11 & Histology of pancreas & $\begin{array}{l}\text { PFA and paraffin } \\
\text { Staining for insulin and Ki67 } \\
\text { PFA and paraffin } \\
\text { Autopsy nondiabetic_-within }\end{array}$ \\
$\begin{array}{l}\text { A h of death } \\
\text { Autopsy diabetic }\end{array}$ & 3 & Histology of pancreas & Frozen sections \\
Surgical-fresh & 10 & Histology of pancreas & Staining for insulin, glucagon, and Ki67 \\
\hline
\end{tabular}

PFA, paraformaldehyde; BrdU, 5-bromo-2'-deoxyuridine.

subjects; additionally, assessment of $\beta$-cell function with measurements of insulin secretion does not accurately reflect $\beta$-cell mass.

A model for determining the potential of human $\beta$-cell replication and neogenesis is to study human islet and duct tissue transplanted under the kidney capsule of immunocompromised mice. Studies using this model have provided evidence that there is potential for regeneration through $\beta$-cell replication and neogenesis $(13,26,27,29)$. The findings of Suarez-Pinzon et al. are of particular interest because they found that human pancreatic duct cells in grafts had a large number of cells that were double stained for cytokeratin 19 (CK19) and insulin, and this number increased markedly to over 50\% of the CK19 population after stimulation with gastrin and GLP-1 (26). These findings with double-stained cells provide evidence that neogenesis was active in these grafts and could be stimulated. The aim of the current study is to use the same model to extend these findings.

\section{MATERIALS AND METHODS}

Human Pancreases From Cadaver Donors, Autopsies, and Fresh Pancreatic Tissue Obtained at Surgery (Table 1)

Human cadaveric pancreases were obtained from brain-dead donors by the New England Organ Bank (Waltham, MA, USA) after obtaining informed consent from donor relatives. The medical records of 13 donors from whom islets were obtained were reviewed for the absence of diabetes and other parameters including age, height, and weight. Donor information is shown in Table 2. Additional cadaver donor pancreases obtained from 11 subjects without diabetes were used for immunohistological examination (ages 15-58, mean 42; five males and six females). The cold ischemic time for both groups of cadaver pancreases ranged from 4 to $16 \mathrm{~h}$. Additional tissue was evaluated from 10 other pancreases [seven nondiabetic (ages 67-81, mean 74) and three diabetic (ages 65-80, mean 76)] from Sweden (Uppsala University Archives, Uppsala, Sweden), which were obtained for autopsy within 4 h of death (see Results). Finally, frozen sections of fresh pancreas were obtained from patients in Sweden undergoing pancreatic surgery. Tissues from 10 patients (ages 33-84, mean 61; seven male and three female) were examined for Ki67 staining. Of the 10 patients, none had diabetes, nine had adenocarcinoma with almost all having Whipple surgery, and one had a questionable insulinoma. The sections studied were all distant from the tumors. Informed consent and appropriate ethical approval were obtained for the use of all human tissue samples.

\section{Human Islet Isolation and Mouse Transplantation}

Human islets and remaining exocrine tissue were isolated in the Human Islet Isolation Laboratory at Massachusetts General Hospital (MGH; Boston, MA,

Table 2. Donor Information for Isolated Islet and Exocrine Preparations

\begin{tabular}{lcccc}
\hline Donor & Age & Male/Female & BMI & \% Islet Purity \\
\hline H-0623 & 45 & F & 37 & 95 \\
MGH-39 & 34 & M & 29 & 90 \\
MGH-40 & 70 & F & 31 & 80 \\
MGH-40b & 46 & M & 25.1 & 95 \\
MGH-41 & 53 & F & 22.7 & 90 \\
MGH-42 & 50 & M & 28.1 & 80 \\
MGH-44 & 55 & M & 22.9 & 70 \\
MGH-45 & 44 & F & 48.5 & 95 \\
MGH-49 & 60 & F & 24.8 & 95 \\
MGH-50 & 33 & F & 26.4 & 85 \\
MGH-60 & 42 & M & 31.9 & 90 \\
MGH-63 & 44 & M & 40.7 & 90 \\
MGH-68 & 34 & M & 35.4 & 85 \\
\hline
\end{tabular}

BMI, body mass index. 
USA) using the standard collagenase/protease (Roche, Indianapolis, IL, USA) digestion method (20). The exocrine tissue immediately after isolation consists almost entirely of acinar and duct cells, but when either cultured or transplanted, the acinar cells in the preparation disappear. Male Institute of Cancer Research/severe combined immunodeficient (ICR-SCID) mice (Taconic Farms, Inc., Hudson, NY, USA) were anesthetized using ketamine (Putney, Inc., Portland, ME, USA)/xylazine (Anased, Shenandoah, IA, USA) and placed on a heated plate for surgery. The left kidney was exposed through a lumbar incision. Then using a Hamilton syringe (Fisher, Pittsburg, PA, USA) and the PE50 polyethylene tubing (Becton Dickinson, Sparks, MD, USA), 1,000 human islet equivalents (IEQs) or 1 million cells of the exocrine fraction obtained from the islet isolation procedure were placed under the kidney capsule as previously described (5). Both islets and the exocrine fraction were transplanted immediately after the isolation. Mice were about 12 weeks old when transplanted and weighed an average of $33 \mathrm{~g}$. Body weight (BW) and blood glucose (BG) were monitored once per week at $9 \mathrm{am}$. BG was measured on blood obtained from the tip of the tail using a OneTouch Ultra ${ }^{\circledR}$ blood glucose meter (Life Scan, Inc., Milpitas, CA, USA). For almost all experiments, grafts were removed 4 weeks after transplantation. However, a small number of grafts were removed at 14 weeks to determine if $\beta$-cell replication was maintained for this longer period of time. All animal experiments were approved by the Joslin Institutional Animal Care and Use Committee.

\section{Streptozocin-Treated Mice}

Diabetes in ICR-SCID mice was induced by a single intraperitoneal (IP) injection of streptozocin $(180 \mathrm{mg} / \mathrm{dl}$ STZ, Sigma-Aldrich, St. Louis, MO, USA). Mice with fed blood sugar levels of $>350 \mathrm{mg} / \mathrm{dl}$ at 1 week after injection were considered diabetic and suitable for transplant.

\section{Intraperitoneal Glucose Tolerance Test}

For IP glucose tolerance test (IPGTT), mice fasted overnight were injected IP with glucose (Sigma-Aldrich) at $2 \mathrm{~g} / \mathrm{kg}$ BW. Blood glucose from the tail was measured as above at $0,15,30,60$, and 120 min after glucose injection.

\section{Drug Treatment of Mice With Grafts}

There were six treatment groups using non-STZtreated mice (Table 3):

1. Gastrin and exendin-4 treatment (islet grafts). Mice with grafts of human islets (two donors, four recipients) were treated with gastrin and exendin-4. Gastrin [IP at $150 \mu \mathrm{g} / \mathrm{kg} \mathrm{BW}$; (Leu15)-Gastrin I human, SigmaAldrich] was injected twice a day ( 8 am and $6 \mathrm{pm})$ for 3 weeks starting 1 week after transplantation. Exendin-4 $(1 \mathrm{nmol} / \mathrm{kg} \mathrm{BW}$, Eli Lilly and Company, Indianapolis, IN, USA) was injected IP once a day (6 pm) for the final week before sacrifice.

2. Gastrin treatment (islet grafts). Mice with grafts of human islets (two donors, five recipients) were treated with gastrin alone as described above.

3. Exendin-4 treatment (islet grafts). Mice with grafts of human islets (3 donors, 10 recipients) were treated only with exendin- 4 for the final week of 4 weeks as described in 1.

4. Gastrin and EGF treatment (islet grafts). Mice with grafts of human islets (two donors, six recipients) were treated with gastrin (IP at $1 \mathrm{mg} / \mathrm{kg}$ ) plus EGF (IP $30 \mu \mathrm{g} /$ $\mathrm{kg}$, recombinant human epidermal growth factor, BD Biosciences, San Jose, CA, USA); both were given once per day at $6 \mathrm{pm}$ for the last 10 days of the 4-week transplant period.

5. Exendin-4 treatment (exocrine cell grafts). Mice with grafts of pancreatic exocrine cells (4 donors, 14 recipients) were treated with exendin- 4 for the final week of 4 weeks as described in 1 .

Table 3. Drug Treatment of Nondiabetic Mice Carrying Transplants of Human Pancreatic Islets or Exocrine Tissue

\begin{tabular}{|c|c|c|c|c|c|}
\hline Group No. & Treatment & Graft & Donors/Recipients & Drug Regimen & Time of Graft Collection \\
\hline 1 & $\begin{array}{c}\text { Gastrin and } \\
\text { exendin-4 }\end{array}$ & Islets & 2 donors, 4 recipients & $\begin{array}{l}\text { Gastrin bid. final } 3 \text { weeks, } \\
\text { Exendin qd final } 1 \text { week }\end{array}$ & 4 weeks after $\mathrm{Tx}$ \\
\hline 2 & Gastrin & Islets & 2 donors, 5 recipients & Gastrin bid final 3 weeks & 4 weeks after $\mathrm{Tx}$ \\
\hline 3 & Exendin-4 & Islets & 3 donors, 10 recipients & Exendin qd final 1 week & 4 weeks after Tx \\
\hline 4 & Gastrin and EGF & Islets & 2 donors, 6 recipients & $\begin{array}{l}\text { Gastrin and EGF, both qd } \\
\text { for last } 10 \text { days }\end{array}$ & 4 weeks after Tx \\
\hline 5 & Exendin-4 & Exocrine & 4 donors, 14 recipients & Exendin qd for final 1 week & 4 weeks after Tx \\
\hline 6 & Gastrin and EGF & Exocrine & 2 donors, 6 recipients & $\begin{array}{l}\text { Gastrin and EGF, both qd } \\
\text { for last } 10 \text { days }\end{array}$ & 4 weeks after Tx \\
\hline
\end{tabular}

See Materials and Methods for further details. Tx, transplant; EGF, epithelial growth factor; qd, treatment once daily; bid, treatment twice daily. 
A.

\section{IPGTT 4 weeks after Tx \\ Donor MGH-060}

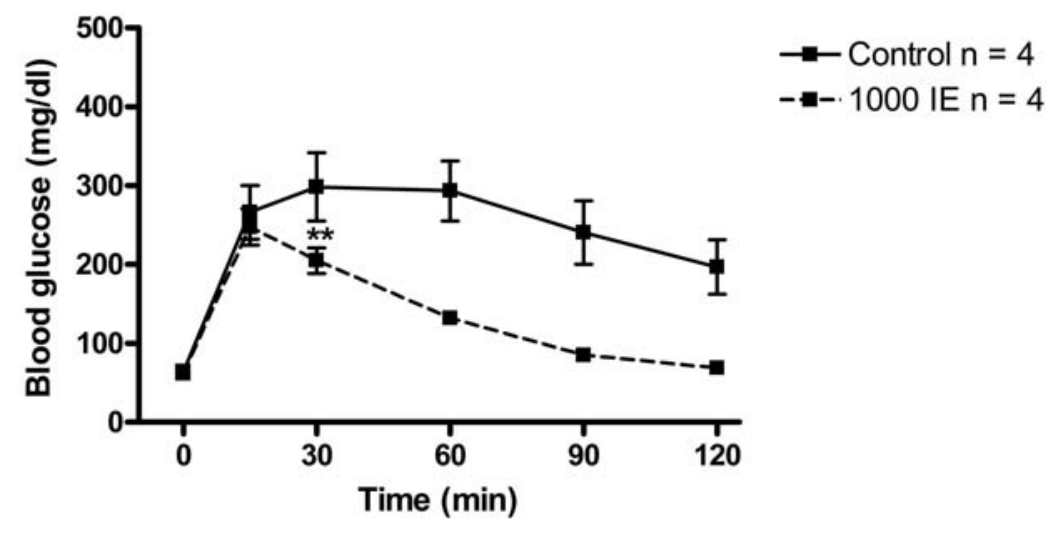

B.

\section{IPGTT 8 weeks after Tx \\ Donor MGH-042}

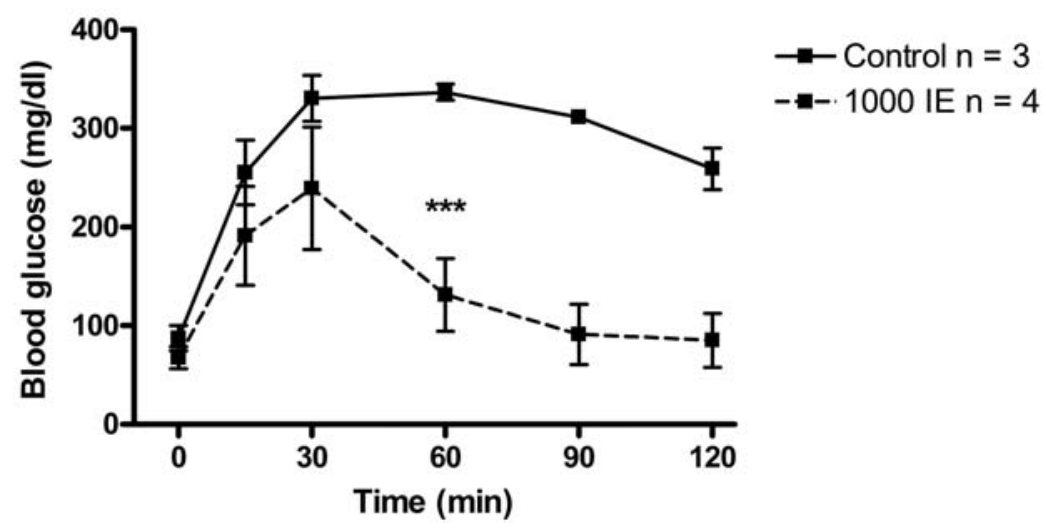

Figure 1. IP glucose tolerance test (IPGTT) performed in non-streptozocin (STZ) Institute of Cancer Research-severe combined immunodeficient (ICR-SCID) mice transplanted with 1,000 islet equivalent (IEQ) human islets and nontransplanted mice (controls). Glucose $[2 \mathrm{~g} / \mathrm{kg}$ body weight (BW)] was injected at time 0. (A) IPGTT after 4 weeks transplantation (Tx) of human islets from donor MGH-060. Mice were 16 weeks old at the time of IPGTT. (B) IPGTT after 8 weeks Tx of human islets from donor MGH-042. Mice were 18 weeks of age. Results are expressed as mean \pm SEM. $* * p<0.01$ and $* * * p<0.001$.

6. Gastrin and EGF treatment (exocrine cell grafts). Mice with grafts of pancreatic exocrine cells (two donors, six recipients) were treated with gastrin plus EGF as described in 4.

\section{BrdU Injection}

Freshly made 5-bromo-2'-deoxyuridine (BrdU) (IP $100 \mathrm{mg} / \mathrm{kg}$ BW; Sigma-Aldrich) was injected into mice at 8 -h intervals $24 \mathrm{~h}$ prior to sacrifice.

\section{Tissue Processing and Immunostaining}

Kidneys containing the grafts were excised from anesthetized mice and fixed in 4\% paraformaldehyde (PFA; Sigma-Aldrich) for $2 \mathrm{~h}$ and stored in PBS (Sigma-Aldrich) at $4^{\circ} \mathrm{C}$ until paraffin embedding. Sections $(5 \mu \mathrm{m})$ were immunostained for insulin, glucagon, Ki67, BrdU, and CK19 and evaluated with the terminal deoxynucleotidyl transferase dUTP nick end labeling (TUNEL) assay. After hydration, sections were blocked with an avidin-biotin 
blocking kit (Vector Laboratories, Inc., Burlingame, CA, USA) per manufacturer's instructions and normal donkey serum (Jackson ImmunoResearch Laboratories, Inc., West Grove, PA, USA) 1:50 for $1 \mathrm{~h}$ at room temperature (RT). For Ki67, BrdU, and CK19 immunostaining, sections were first soaked in $0.3 \%$ Triton ${ }^{\circledR}$ X-100 (SigmaAldrich) in PBS for $15 \mathrm{~min}$, followed by two washes, and microwaved for antigen retrieval in $0.01 \mathrm{M}$ sodium citrate buffer pH 4.0 (Sigma-Aldrich) for $20 \mathrm{~min}$. Before immunolabeling, fresh frozen sections were fixed in cold PFA for 10 min at $-20^{\circ} \mathrm{C}$ followed by 10 min at $4^{\circ} \mathrm{C}$ and then by 20 min in PBS at RT and blocked with $0.2 \%$ glycerol (Sigma-Aldrich) in PBS for 5 min. Then the slides were treated with an avidin-biotin blocking kit and normal donkey serum as described above.

Primary antibodies were guinea pig anti-insulin (4011-01; Linco Research, St. Charles, MO, USA; overnight at $4^{\circ} \mathrm{C}$ ), rabbit anti-glucagon antibody (AB932, Millipore, Billerica, MA, USA, 1:3,000, overnight at $4^{\circ} \mathrm{C}$ ), mouse anti-human Ki67 (BD Pharmingen, 556003, San Jose, CA, USA; $1: 50$ overnight at $4^{\circ} \mathrm{C}$ or 1:200 for frozen sections; SP6; rabbit monoclonal; Abcam, Cambridge, UK; 1:50 and 1:100 for formalin-fixed sections), mouse anti-BrdU (M0744, Dako North America, Inc., Carpinteria, CA, USA; $1: 50$ overnight at $4{ }^{\circ} \mathrm{C}$ ), and mouse anti-human CK19 (M0888, Dako North America, Inc., 1:50, overnight at $4^{\circ} \mathrm{C}$ ). Secondary antibodies used for $1 \mathrm{~h}$ at RT were biotinylated donkey anti-rabbit IgG (Jackson ImmunoResearch Laboratories, Inc.; 1:400) or biotinylated donkey anti-mouse IgG (Jackson ImmunoResearch Laboratories, Inc.; 1:200) followed by streptavidin-conjugated Alexa Fluor $^{\circledR} 488$ (Invitrogen, Carlsbad, CA, USA; 1:400) or for CK19, cyanine 3 (Сy3)-conjugated donkey anti-mouse IgG (Jackson ImmunoResearch Laboratories, Inc.; 1:200) for $1 \mathrm{~h}$.
Then to visualize the hormone-expressing cells, the sections were incubated for 90 min at RT with guinea pig anti-human insulin (AB2440, Millipore; 1:200 in PBS) or rabbit anti-glucagon antibody (AB932, Millipore; 1:200) followed by washes and incubation with Texas Red-conjugated anti-species-specific IgG (Jackson ImmunoResearch Laboratories, Inc.; 1:200) or fluorescein isothiocyanate (FITC)-conjugated donkey anti-speciesspecific IgG (Jackson ImmunoResearch Laboratories, Inc.; 1:400) for $90 \mathrm{~min}$ at RT.

\section{TUNEL and Insulin Staining}

The In Situ Cell Death Detection Kit, Fluorescein (Roche Diagnostics, Indianapolis, IN, USA) was used for TUNEL, following the manufacturer's instructions using microwave retrieval and then immunostaining for insulin as described above.

\section{Image Capturing and Analysis}

Images were taken using an Olympus BH2 scope connected with Olympus DP71 camera (Olympus America, Inc., Center Valley, PA, USA) using DP controller program. Pictures were opened with Adobe Photoshop (San Francisco, CA, USA), and cells were counted manually. Alternatively, confocal images were obtained using LSM-710 confocal microscopy (Carl Zeiss Microscopy, LLC, Thornwood, NY, USA) with optical Z-sections every $0.45 \mu \mathrm{m}$.

\section{Statistics}

Data are reported as mean \pm standard error (SEM). Correlations were made with the Pearson product moment correlation coefficient. Statistical significance was assessed with the two-tailed Student's $t$ test.
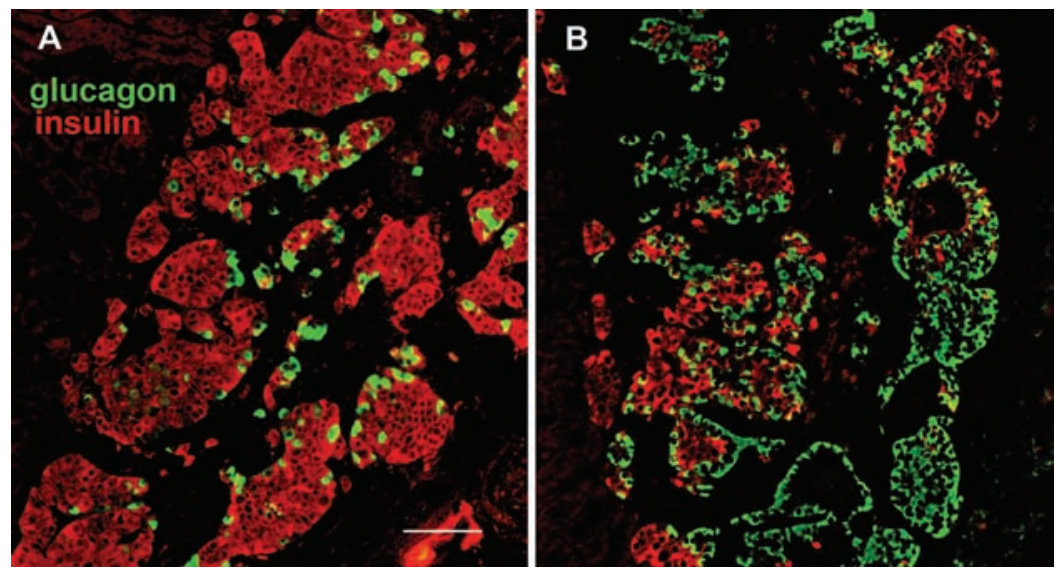

Figure 2. Human islets engrafted under the mouse kidney capsule immunostained for insulin (red) and glucagon (green). Islets from donor MGH-39 (A) and donor MGH-63 (B). Scale bar: $100 \mu \mathrm{m}$. 
Table 4. Insulin and Glucagon Ratio ( $\beta$ - and $\alpha$-Cell Ratio) From Human Islets Transplanted Under the Kidney Capsule of Non-STZ Normoglycemic ICR-SCID Mice

\begin{tabular}{lcccc}
\hline Donor & $\begin{array}{c}\text { Insulin/Glucagon } \\
\text { 4 Weeks }\end{array}$ & $\begin{array}{c}\text { Number Grafts/ } \\
\text { Total Insulin Cells }\end{array}$ & $\begin{array}{c}\text { Insulin/Glucagon } \\
14 \text { Weeks }\end{array}$ & $\begin{array}{c}\text { Number Grafts/ } \\
\text { Total Insulin Cells }\end{array}$ \\
\hline MGH-39 & $4.30 \pm 0.83$ & $5 / 8,654$ & - & - \\
MGH-40 & $1.14 \pm 0.21$ & $7 / 7,755$ & - & - \\
MGH-40b & $1.95 \pm 0.27$ & $6 / 6,082$ & - & - \\
MGH-41 & $1.09 \pm 0.20$ & $4 / 2,143$ & - & - \\
MGH-42 & - & - & $1.32 \pm 0.17$ & $6 / 6,970$ \\
MGH-44 & $2.46 \pm 0.81$ & $3 / 1,764$ & - & - \\
MGH-45 & $2.40 \pm 0.52$ & $4 / 5,153$ & $2.40 \pm 0.40$ & $3 / 3,832$ \\
MGH-49 & - & - & $1.70 \pm 0.60$ & - \\
MGH-50 & $1.70 \pm 0.40$ & $4 / 9,758$ & $1.50 \pm 0.20$ & $2 / 1,844$ \\
MGH-60 & $1.34 \pm 0.11$ & $3 / 2,362$ & - & - \\
MGH-63 & $0.47 \pm 0.06$ & $4 / 1,181$ & - & - \\
MGH-68 & 1.54 & $1 / 477$ & 1.73 & $4 / 5,131$ \\
Mean & 1.84 & $4 / 4,533$ & 0.24 & \\
SEM & 0.33 & & & - \\
\hline
\end{tabular}

Number of grafts corresponds to the number of mice transplanted with islets from the same donor, stained for insulin and glucagon, and the total of insulin-positive cells counted from all the grafts. Results are expressed as mean \pm SEM. STZ, streptozocin; ICR-SCID, Institute of Cancer Research-severe combined immunodeficient.

\section{RESULTS}

\section{IPGTTs in ICR-SCID Mice Transplanted With Human Islets}

IPGTTs were performed in non-STZ-treated ICR-SCID mice 4 and 8 weeks after transplantation. In mice engrafted with 1,000 IEQ human islets from a single islet isolation (MGH-060) for 4 weeks (Fig. 1A), glucose clearance after glucose injection was clearly more efficient than in control mice, being significant $(p<0.01)$ at $30 \mathrm{~min}$ and after. Mice transplanted with another batch of human islets (MGH042, 1,000 IEQs) for 8 weeks had similarly improved blood glucose clearance after the glucose challenge (Fig. 1B). Fasting glucose levels did not differ significantly between these two groups ( $61 \pm 5$ in transplanted vs. $74 \pm 7 \mathrm{mg} / \mathrm{dl}$ in the nontransplanted controls, $p=0.14$ ). Fed blood glucose levels measured simultaneously 24 times (using eight transplanted and seven control mice) were lower in the transplanted group compared to the control mice (155 \pm 3 and $169 \pm 4$, respectively, $p=0.008$ ).

\section{Insulin and Glucagon Ratio in Grafts of ICR-SCID Mice Transplanted With Human Islets}

The ratio of insulin-stained to glucagon-stained cells was determined in grafts of non-STZ-treated mice transplanted with human islets (1,000 IEQs) under the kidney capsule (Fig. 2). Table 4 shows that the $\beta / \alpha$-cell ratio ranged from 0.47 to 4.30 with a mean of $1.84 \pm 0.33$ in grafts removed 4 weeks after transplantation and from 1.32 to 2.40 with a mean of $1.73 \pm 0.24$ in grafts removed 14 weeks after transplantation. For two donors, grafts were assessed at both 4 and 14 weeks and when compared, and the $\beta / \alpha$-cell ratios remained essentially the same. There was no correlation between the $\beta / \alpha$-cell ratio and either body mass index (BMI; $r^{2}=0.01, p=0.75$ ) or age $\left(r^{2}=0.11, p=0.34\right)$ of the donors.

\section{$\beta$-Cell Replication in Grafts After 4 and 14 Weeks Transplantation}

$\beta$-Cells replicated at a low frequency in grafts 4 and 14 weeks after transplantation into non-STZ-treated recipients. Replication of $\beta$-cells was identified by double immunostaining for the replication marker Ki67 and insulin (Fig. 3). The percentage of insulin-positive cells replicating (Ki67 positive) in grafts ranged from $0.06 \%$ to $0.42 \%$ after 4 weeks of transplantation, while being $0.08-0.22 \%$ after 14 weeks of transplantation, as shown in Table 5. There is no correlation between the percentage on $\mathrm{Ki}^{+} 7^{+}$insulin $^{+}$cells
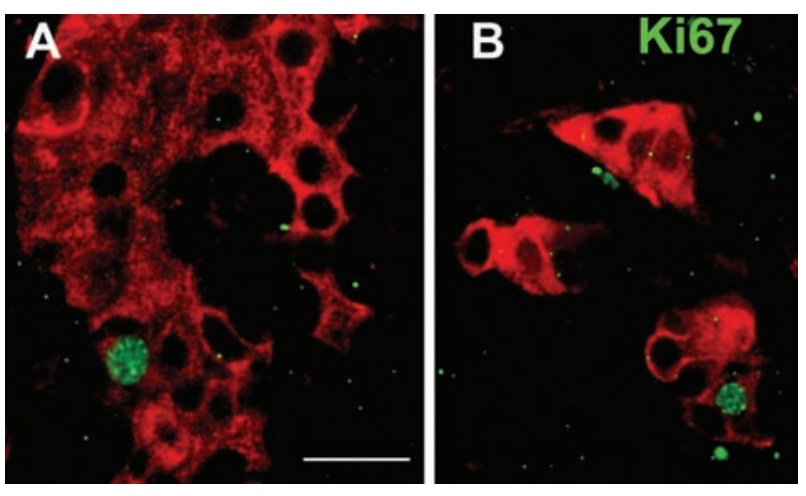

Figure 3. Human islets engrafted under the mouse kidney capsule immunostained for insulin (red) and Ki67 (green). (A) and (B) represent examples of insulin-containing cells stained with Ki67. Scale bar: $20 \mu \mathrm{m}$. 
Table 5. Percentage of Double-Positive Cells for Ki67 and Insulin in Grafts From Non-STZ ICR-SCID Mice Transplanted With Human Islets After 4 and 14 Weeks

\begin{tabular}{lcccc}
\hline Donor & $\begin{array}{c}\text { \% Ki67-Insulin } \\
\text { 4 Weeks }\end{array}$ & $\begin{array}{c}\text { Number Grafts/ } \\
\text { Total Insulin Cells }\end{array}$ & $\begin{array}{c}\text { \% Ki67-Insulin } \\
14 \text { Weeks }\end{array}$ & $\begin{array}{c}\text { Number Grafts/ } \\
\text { Total Insulin Cells }\end{array}$ \\
\hline MGH-39 & $0.42 \pm 0.03$ & $4 / 9,598$ & - & - \\
MGH-40 & $0.11 \pm 0.03$ & $7 / 15,471$ & - & - \\
MGH-40b & $0.06 \pm 0.01$ & $6 / 12,764$ & - & - \\
MGH-41 & $0.35 \pm 0.10$ & $3 / 5,673$ & - & $6 / 11,167$ \\
MGH-42 & - & - & $0.10 \pm 0.03$ & - \\
MGH-44 & $0.17 \pm 0.05$ & $3 / 7,269$ & - & $3 / 6,792$ \\
MGH-45 & $0.21 \pm 0.07$ & $3 / 7,433$ & $0.10 \pm 0.03$ & $5 / 14,746$ \\
MGH-49 & - & - & $0.08 \pm 0.01$ & - \\
MGH-50 & $0.27 \pm 0.07$ & $4 / 9,738$ & - & $2 / 5,438$ \\
MGH-60 & $0.19 \pm 0.05$ & $3 / 6,789$ & $0.22 \pm 0.03$ & - \\
MGH-63 & $0.20 \pm 0.05$ & $3 / 6,568$ & - & - \\
MGH-68 & $0.24 \pm 0.06$ & $3 / 6,725$ & - & $4 / 9,536$ \\
Mean & 0.22 & $4 / 8,803$ & 0.13 & 0.03 \\
SEM & 0.03 & & & - \\
\hline
\end{tabular}

There are no significant differences between $\%$ Ki67-insulin at 4 weeks versus 14 weeks after transplantation $(p=0.12$, unpaired $t$ test). Results are expressed as mean \pm SEM.

and either BMI $\left(r^{2}=0.007, p=0.8\right)$ or age of the donors $\left(r^{2}=0.23, p=0.15\right)$. $\beta$-Cell replication was also assessed by BrdU incorporation $24 \mathrm{~h}$ after administration (Table 6). The percentage of $\mathrm{BrdU}^{+}$insulin $^{+}$cells 4 weeks after transplantation in the control nontreated group and EGF-gastrin group was $0.17 \pm 0.06 \%$ and $0.15 \pm 0.04 \%$, respectively. Gastrin alone, gastrin and exendin-4, exendin- 4 alone, and gastrin and EGF treatments did not increase $\beta$-cell replication in human islets engrafted into non-STZ mice, as shown in Figure 4.

We also assessed $\beta$-cell death by TUNEL and insulin double staining from nontreated controls at 4 and 14 weeks, and groups treated with exendin-4, gastrin, gastrin + exendin-4, and gastrin + EGF at 4 weeks. The percentage results of TUNEL ${ }^{+}$insulin $^{+}$cells in these groups were $0.14 \pm 0.02,0.12 \pm 0.02,0.10 \pm 0.03,0.21 \pm 0.05$, $0.14(n=1), 0.07 \pm 0.05$, respectively. For each of these conditions, between 2,137 and 6,286 insulin-positive cells were examined. All of these mice were non-STZ treated.
Examination of Human Cadaveric and Autopsy Pancreases, and Frozen Pancreatic Biopsies for $\beta$-Cell Replication

When formalin-fixed paraffin sections of 11 cadaveric pancreases (subject ages 15-58, mean 42) were stained for Ki67 and insulin, no Ki67 ${ }^{+}$insulin $^{+}$cells were found after analyzing a total of 596 islets with an average of $40 \beta$-cells per islet. Indeed, no Ki67-positive cells were found in any of the sections.

A second group of seven pancreases from nondiabetic individuals (ages 67-81, mean 74) obtained within $4 \mathrm{~h}$ after death were available from the archive at Uppsala University and immunolabeled with Ki67 antibody after antigen retrieval. This antibody works well on formalinfixed frozen sections (positive control). In addition, three cases with diabetes were included (ages 65-80, mean 76). No positive nuclei could be detected in any of the cases.

However, when frozen pancreatic biopsies were similarly double stained for Ki67 and insulin, $12 \mathrm{Ki}^{+} 7^{+}$insulin $^{+}$

Table 6. Percentage of Double-Positive Cells Stained for BrdU and Insulin in Human Islet Grafts of Non-STZ ICR-SCID Mice

\begin{tabular}{lcccc}
\hline Donor & $\begin{array}{c}\text { Control } \\
\text { \% BrdU-Insulin }\end{array}$ & $\begin{array}{c}\text { Number Grafts/ } \\
\text { Total Insulin Cells }\end{array}$ & $\begin{array}{c}\text { EGF-Gastrin } \\
\text { \% BrdU-Insulin }\end{array}$ & $\begin{array}{c}\text { Number Grafts/ } \\
\text { Total Insulin Cells }\end{array}$ \\
\hline MGH-63 & $0.11 \pm 0.04$ & $3 / 6,928$ & $0.11 \pm 0.06$ & $3 / 5,242$ \\
MGH-68 & $0.22 \pm 0.04$ & $3 / 6,725$ & $0.19 \pm 0.03$ & $4 / 9,446$ \\
Mean & 0.17 & $3 / 6,827$ & 0.15 & $3 / 7,344$ \\
SEM & 0.06 & & 0.04 & \\
\hline
\end{tabular}

Grafts from non-STZ-treated mice were injected with 5-bromo-2'-deoxyuridine (BrdU) $24 \mathrm{~h}$ prior to sacrifice in 8-h intervals. The table shows the results from control and epidermal growth factor (EGF)-gastrin-treated mice, and data are expressed as mean \pm SEM 
A.

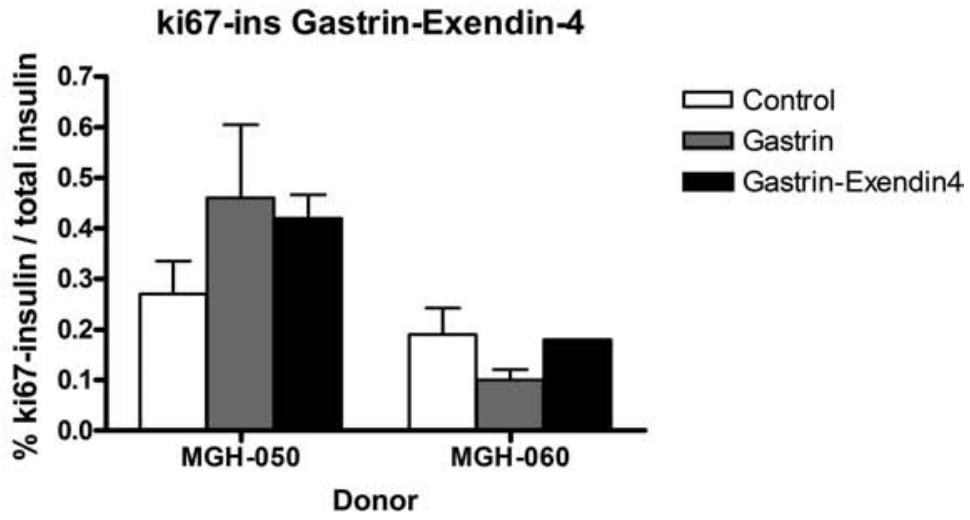

B.

ki67-ins Exendin-4

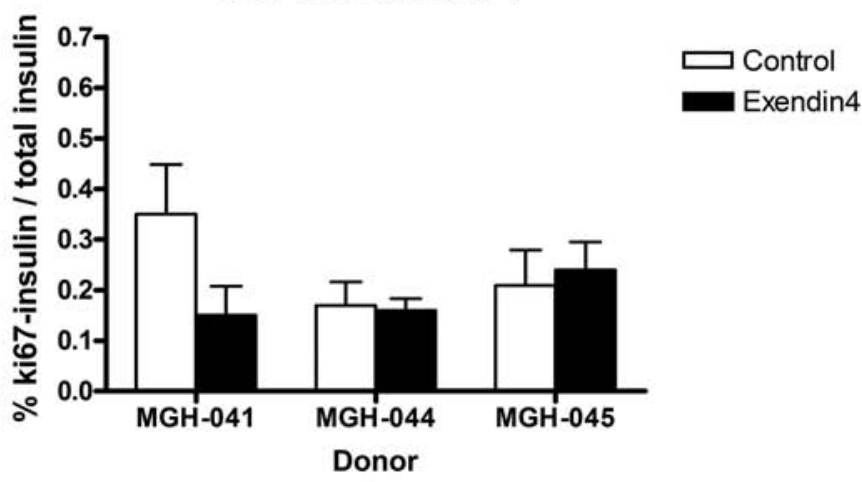

C.

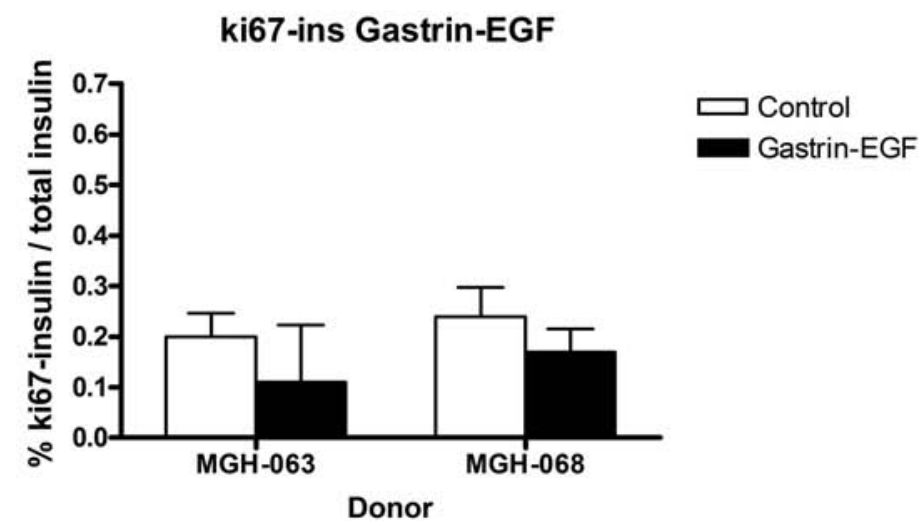

Figure 4. Percentage of double-positive Ki67 and insulin cells in human islet grafts after different treatments. Percentage of doublepositive Ki67 and insulin cells in human islet grafts transplanted under the kidney capsule of non-STZ ICR-SCID mice for 4 weeks and treated with (A) gastrin alone, $150 \mu \mathrm{g} / \mathrm{kg}$, twice a day $(8 \mathrm{am}$ and $6 \mathrm{pm})$ for 3 weeks or gastrin (same dosage) + exendin- $4,1 \mathrm{nmol} /$ $\mathrm{kg}$ once a day $(6 \mathrm{pm})$ for 1 week; (B) exendin-4, $1 \mathrm{nmol} / \mathrm{kg}$, once a day $(6 \mathrm{pm})$ for 1 week; and (C) epidermal growth factor (EGF), $30 \mu \mathrm{g} / \mathrm{kg}$, and gastrin, $1 \mathrm{mg} / \mathrm{kg}$, once a day for 10 days. Control bars represent mice transplanted with human islets but no drug treatment. Results are expressed as mean \pm SEM. 
Table 7. Insulin/Glucagon Ratio and \% Ki67-Insulin-Positive Cells of Human Islet Grafts From Diabetic and Nondiabetic ICR-SCID Mice

\begin{tabular}{lcccc}
\hline & Insulin/Glucagon & $\begin{array}{c}\text { Number Grafts/ } \\
\text { Total Insulin Cells }\end{array}$ & \% Ki67-Insulin & $\begin{array}{c}\text { Number Grafts/ } \\
\text { Total Insulin Cells }\end{array}$ \\
\hline Diabetics & $1.40 \pm 0.08$ & $5 / 1,247$ & $0.89 \pm 0.25$ & $5 / 2,445$ \\
Cured & 2.22 & $1 / 901$ & 0.42 & $1 / 1,388$ \\
Controls & $2.94 \pm 0.36 *$ & $6 / 3,578$ & $0.63 \pm 0.17$ & $5 / 7,856$ \\
\hline
\end{tabular}

Insulin/glucagon ratio and \% Ki67-insulin-positive cells in human islet grafts (donor H-0623) transplanted into STZ-treated hyperglycemic mice (diabetics) and non-STZ-treated normoglycemic mice (controls). Cured refers to a STZ-treated hyperglycemic mouse that became normoglycemic after transplantation. Results expressed as mean \pm SEM. ${ }^{*} p=0.007$.

of a total of 6,630 insulin cells were found $(0.18 \%$ Ki67 ${ }^{+}$insulin ${ }^{+}$). Moreover, all pancreatic frozen biopsies had Ki67-positive cells other than insulin-positive cells, which were non- $\beta$-islet cells, exocrine cells, or nonidentified cells.

\section{Human Islets Transplanted Into Diabetic STZ-Treated Mice}

In a separate experiment, human islets (1,000 IEQs, donor H0623B) were similarly transplanted under the kidney capsule of normoglycemic non-STZ-treated and STZ-treated diabetic ICR-SCID mice. One of six diabetic mice became normoglycemic 1 week after transplantation, remaining normal for 4 weeks. The $\beta / \alpha$-cell ratio was significantly lower in islets engrafted in diabetic mice than in the normoglycemic recipients $(n=6 ; 1.40 \pm 0.08$ vs. 2.94 $\pm 0.36, p=0.007$ ). However, no difference was found in $\beta$-cell replication as assessed by counting cells double stained for Ki67 and insulin (Table 7).

\section{$\beta$-Cell Neogenesis From Human Duct Cells}

Human exocrine tissue was transplanted under the kidney capsule of normoglycemic non-STZ-treated ICRSCID mice, the grafts were retrieved after 4 weeks, and double staining was performed for CK19 and either insulin or glucagon (Fig. 5). By 4 weeks, no acinar cells could be found, and the graft consisted almost entirely of duct cells. Table 8 shows the number of insulin and glucagon cells found within or outside of duct structures as identified by CK19-positive cells. These cells were few in number, and there was no evidence that any of the drug treatments increased the frequency of insulin- or glucagonpositive cells in either location. To look further for evidence of neogenesis, 12 insulin-positive cells within the duct epithelium were analyzed to see if they expressed the duct marker CK19 as well. By doing confocal optical z-stacks, we found that 7 of these 12 cells expressed both CK19 and insulin (Fig. 6).

\section{DISCUSSION}

The present study examines grafts of human islets transplanted under the kidney capsule of immunocompromised ICR-SCID mice with regard to cell composition and the regenerative potential of $\beta$-cells by replication and neogenesis.

There has been a surprising amount of disagreement about $\beta$-cells as a percentage of total islet cells in the adult human pancreas with estimates varying from $50 \%$
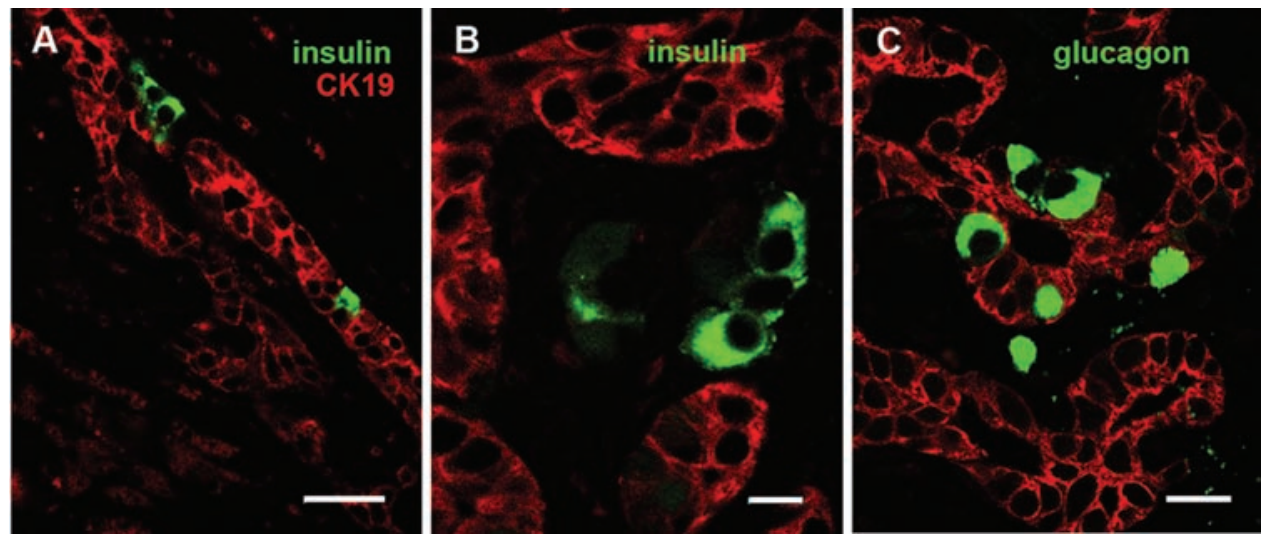

Figure 5. Human exocrine tissue engrafted under kidney capsule had hormone-positive cells within the ductal structures. Immunostaining for CK19 (red) for ducts and insulin (green) (A, B) and glucagon (green) (C). In (B), the insulin-positive cells (green) are outside of the duct (red). Scale bars: $50 \mu \mathrm{m}$ (A), $10 \mu \mathrm{m}$ (B), and $25 \mu \mathrm{m}$ (C). 
Table 8. Exocrine Tissue Transplanted Under the Kidney Capsule of Non-STZ Normoglycemic ICR-SCID Mice

\begin{tabular}{|c|c|c|c|c|c|c|c|}
\hline Donor & Conditions & $\begin{array}{c}\text { Insulin } \\
\text { Out Ducts }\end{array}$ & $\begin{array}{l}\text { Insulin } \\
\text { In Ducts }\end{array}$ & $n$ (Grafts) & CK19 & $\begin{array}{c}\text { Insulin Out } \\
\text { Ducts/CK19\% }\end{array}$ & $\begin{array}{c}\text { Insulin In } \\
\text { Ducts/CK19\% }\end{array}$ \\
\hline \multicolumn{8}{|c|}{ a) Number of insulin-positive cells in and out of the duct epithelium } \\
\hline \multirow[t]{2}{*}{ MGH-040 } & control & 25 & 1 & 3 & 2,127 & 1.18 & 0.05 \\
\hline & exendin-4 & 52 & 1 & 4 & 4,032 & 1.29 & 0.02 \\
\hline \multirow[t]{2}{*}{ MGH-040B } & control & 0 & 3 & 4 & 4,397 & 0 & 0.07 \\
\hline & exendin-4 & 0 & 2 & 2 & 959 & 0 & 0.21 \\
\hline \multirow[t]{2}{*}{ MGH-041 } & control & 0 & 0 & 2 & 1,089 & 0 & 0 \\
\hline & exendin-4 & 1 & 2 & 4 & 2,228 & 0.04 & 0.09 \\
\hline \multirow[t]{2}{*}{ MGH-042 } & control & 7 & 23 & 3 & 4,052 & 0.17 & 0.57 \\
\hline & exendin-4 & 4 & 12 & 4 & 5,154 & 0.08 & 0.23 \\
\hline \multirow[t]{2}{*}{ MGH-063 } & control & 0 & 2 & 1 & 587 & 0 & 0.34 \\
\hline & gastrin-EGF & 3 & 5 & 3 & 5,158 & 0.06 & 0.10 \\
\hline \multirow{2}{*}{ MGH-068 } & control & 1 & 5 & 3 & 4,760 & 0.02 & 0.11 \\
\hline & gastrin-EGF & 9 & 9 & 3 & 5,066 & 0.18 & 0.18 \\
\hline Donor & Conditions & $\begin{array}{l}\text { Glucagon } \\
\text { Out Ducts }\end{array}$ & $\begin{array}{l}\text { Glucagon } \\
\text { In Ducts }\end{array}$ & $n$ (Grafts) & CK19 & $\begin{array}{l}\text { Glucagon Out } \\
\text { Ducts/CK19\% }\end{array}$ & $\begin{array}{c}\text { Glucagon In } \\
\text { Ducts/CK19\% }\end{array}$ \\
\hline \multicolumn{8}{|c|}{ b) Number of glucagon-positive cells in and out of the duct epithelium } \\
\hline \multirow[t]{2}{*}{ MGH-042 } & control & 1 & 3 & 3 & 2,450 & 0.04 & 0.12 \\
\hline & exendin-4 & 0 & 10 & 4 & 3,619 & 0 & 0.28 \\
\hline \multirow[t]{2}{*}{ MGH-063 } & control & 0 & 5 & 1 & 587 & 0 & 0.85 \\
\hline & gastrin-EGF & 2 & 11 & 3 & 5,158 & 0.04 & 0.21 \\
\hline \multirow[t]{2}{*}{ MGH-068 } & control & 0 & 2 & 3 & 4,760 & 0 & 0.04 \\
\hline & gastrin-EGF & 0 & 1 & 3 & 5,066 & 0 & 0.02 \\
\hline
\end{tabular}

to over $80 \%$, as has been recently reviewed (18). Our analysis using electron microscopic determination of islet cell type on preparations of isolated human islets obtained a value of $73.6 \%$ (18). In our present study, the ratio of insulin- to glucagon-stained cells in human islet grafts ranged from 0.47 to 4.3 , with a mean of 1.84 (Table 2). Assuming that about 5-10\% of islet cells are neither $\alpha$ - or $\beta$-cells, our data indicate that about $60 \%$ of the islet cells in the grafts were $\beta$-cells, which being lower than $74 \%$ suggests that $\beta$-cells were preferentially lost. This is not very surprising because it is generally thought that $\beta$-cells are more fragile than other cell types. For example, streptozotocin kills $\beta$-cells but not hepatocytes that have a similar glucose transporter 2 (GLUT2) glucose transport mechanism. As noted above, the $\beta / \alpha$-cell ratios varied substantially (ranging from 4.30 to 0.47 ). The paucity of $\beta$-cells in some grafts could be due to a pathological process in the donor, such as type 2 diabetes, that was not recognized during donor selection leading to $\beta$-cell reduction or perhaps resulting from loss of $\beta$-cells during the trauma of isolation. It can be noted that a study of $\alpha$-cell mass in adult human pancreases found surprising variability (7). Interestingly, the survival of human $\alpha$-cells in the grafts is very different from our findings with transplanted rat islets, in which there was a marked preferential loss of $\alpha$-cells in the grafts over a 12-week period (9).
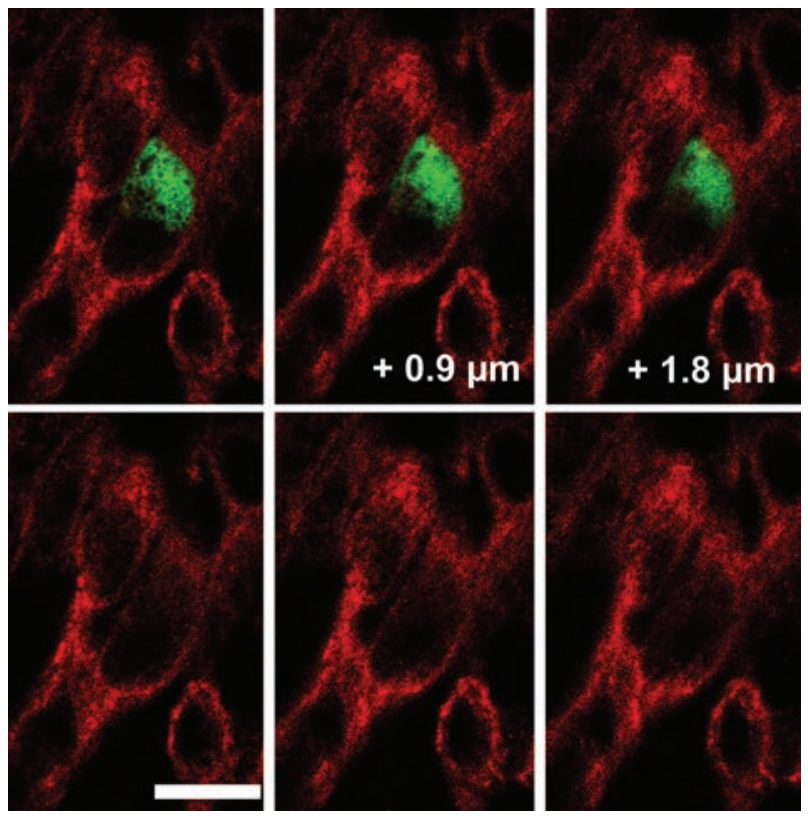

Figure 6. Human exocrine tissue engrafted under kidney capsule had some insulin-positive cells within the ductal structures that coexpressed CK19, the marker of duct cells, suggesting an ongoing process of differentiation. CK19 (red); insulin (green). Three optical sections of a confocal z-stack separated by $0.9 \mu \mathrm{m}$ are shown in the upper panel. Bottom panels show the red channel only to visualize the CK19 immunostaining in the upper panels. Scale bar: $10 \mu \mathrm{m}$. 
$\beta$-Cell replication, albeit at a low level, was found in all of our grafts containing human islets, and the percentage of $\beta$-cells with Ki67 staining averaged $0.22 \%$, which is in general agreement with other studies $(13,29)$. In some of our grafts, the Ki67 staining of $\beta$-cells was over $0.6 \%$. Ki67 appears to be a valid way to mark cells in cell cycle and provides results in general agreement with results obtained with BrdU in our study and proliferating cell nuclear antigen (PCNA) and minichromosome maintenance protein (MCM-7) by others (10). The presence of $\beta$-cells replicating in all the grafts is in sharp contrast to the complete lack of replication found in the donor cadaveric and autopsy pancreases we examined. The remarkable rarity of dividing $\beta$-cells in adult human pancreases has been reported in other studies $(4,8,17,21)$. In a study using cadaver pancreases, $\beta$-cell replication as determined with Ki67 was more prominent in younger donors, but only a minority of pancreases from older donors had measureable replication (8). In contrast, a frequency of Ki67 staining similar to what we see in our grafts was reported in most pancreases in some studies $(11,19)$. It is notable that, in a study examining tissue obtained after partial pancreatectomy surgery in adults, the Ki67 positivity was in the range of $0.5 \%$. Perhaps the values were so high because the tissue was fixed a very short time after surgery (14).

The lack of replication of $\beta$-cells and even acinar cells in our donor cadaveric and autopsy pancreases raised questions about the complexities of Ki67 staining, as has been discussed elsewhere $(2,23)$. However, we could find Ki67 in lymph nodes as a positive control, and others have found Ki67-positive $\beta$-cells in pancreases of younger cadaver donors prepared in the same way as the older donors that had no evidence of $\beta$-cell replication (8). Interestingly, all our frozen sections from human pancreatic biopsies had islet and nonislet Ki67-positive cells, and $\beta$-cells with Ki67 staining averaged $0.18 \%$, similar to what we found in our grafts $(0.22 \%)$. This raises the important question as to whether cadaveric donor and autopsy pancreases lose their Ki67 staining because of events surrounding illness and death and/or because of the way pancreases are handled and preserved before being processed for histology. Thus, it is possible that after a person's death, $\beta$-cells and other cells can remain alive for a period of time but are stressed enough for replication to slow. Then, if rescued by being placed into an in vivo transplant environment, the cells regain their health and can again enter the cell cycle. Therefore, $\beta$-cell turnover from replication in adult pancreases may be higher than previously appreciated and high enough to have an impact.

$\beta$-Cells in the grafts are exposed to glucose levels higher than found in normoglycemic humans because mice normally have higher glucose levels than humans. This is related to the interesting finding that in the IPGTT, glucose is cleared more rapidly in the mice carrying transplanted human $\beta$-cells than controls, which presumably results from the human $\beta$-cells having a lower set point than mouse $\beta$-cells. Thus, there is glycemic stimulation of these cells, which leads to continued insulin secretion that may be linked to increased replication, similar to that seen in a mouse model employing glucose infusions (13). To determine if the observed replication was dependent on the early 4-week time point, we examined grafts 14 weeks after transplantation and found replication at levels only modestly lower than at 4 weeks in all grafts examined.

We also sought to determine if replication could be stimulated by a combination of exendin-4 and gastrin or of gastrin and EGF. These regimens were chosen after consideration of the literature and our own experience. Exendin- 4 has been shown to stimulate $\beta$-cell replication in rats (30). None of these treatments could be found to stimulate replication in our human $\beta$-cells. Because the treatments were given from 10 days to 3 weeks, it is possible we missed an earlier effect. Nonetheless, although we did not measure $\beta$-cell mass, we are concerned that prospects for increasing $\beta$-cell mass using these treatments in human islet transplantation are not encouraging.

We also asked if neogenesis from duct cells to islet cells was present and could be stimulated. We have previously shown that purified human duct cells could produce a small number of insulin-containing cells when transplanted under the kidney capsule of mice (31). There are now several studies showing that various agents can stimulate neogenesis of islet cells from human and rodent pancreatic tissue. Exendin-4, an analog of glucagon-like peptide 1 (GLP-1), has been shown to increase both $\beta$-cell replication and neogenesis in diabetic and control rats (30). Stimulation of neogenesis in mice by combination treatment with gastrin and EGF has also been reported (22). Even gastrin alone has been found to increases $\beta$-cell mass by increasing both $\beta$-cell replication and neogenesis in rats after 95\% pancreatectomy (28). With regard to human pancreatic tissue transplanted under the kidney capsule of immunocompromised mice, combinations of gastrin plus EGF and of gastrin plus GLP-1 have been reported to stimulate neogenesis from pancreatic duct cells $(25,26)$. Strikingly, after 5 weeks of treatment with gastrin and GLP 1, 54\% of the CK19-positive cells in grafts were double stained for insulin compared with only $7 \%$ in the vehicle-treated mice (26).

In our study of neogenesis, we transplanted tissue that was predominantly exocrine but not purified and treated the mice with exendin- 4 for 1 week prior to sacrifice at 4 weeks or with gastrin plus EGF for 10 days prior to sacrifice. We characterized insulin-positive cells outside the duct structures as most likely being $\beta$-cells that were introduced at the time of transplantation. Insulin-positive cells within duct structures were considered better candidates for having been generated by neogenesis. Consistent with 
a neogeneic process, we found more glucagon-positive cells within the duct structures than outside. We were particularly interested in finding cells that were double stained for CK19 and insulin, as these could be markers for neogenesis. Of 12 insulin-positive cells in ducts that were carefully examined with optical sectioning by confocal microscopy, 7 were double positive for insulin and CK19. We interpret this as evidence of a slow process of $\beta$-cell neogenesis from duct cells in a transplant site. Our results are very different from those of Suarez-Pinzon et al. (26). We found less than $1 \%$ of all insulin-positive cells associated with ducts, and only about half of these were double stained for insulin and CK19, which is far less than the $7 \%$ seen in their control vehicle-treated grafts. Our stimulated values for $\mathrm{CK}_{19}{ }^{+}$insulin $^{+}$cells were far lower than theirs; the shorter duration of our treatments seems like only a partial explanation for this major discrepancy.

In conclusion, our grafts of human pancreatic tissue studied 4 and 14 weeks after transplantation into normoglycemic mice show evidence of low levels of $\beta$-cell replication and neogenesis, the latter suggested by cells double stained for insulin and CK19. However, neither process could be stimulated by short-term treatment with agents that included combinations of exendin-4, gastrin, and EGF. Continued generation of $\beta$-cells probably counters what appears to be a slow constant rate of $\beta$-cell death as evidenced by TUNEL staining results. This study supports the concept that human $\beta$-cells have a low level of turnover and the possibility that regeneration could be stimulated with a therapeutic intervention.

ACKNOWLEDGMENTS: The authors thank Alevtina Pinkhasov and Chris Cahill for expert technical assistance. This study was supported by grants from the Juvenile Diabetes Research Foundation (G.C.W.) and the National Institutes of Health NIH R01 DK 66056 and DK 93909 (S.B.W.), P30 DK36836 Joslin Diabetes Research Center (DRC) Advanced Microscopy Core and the Diabetes Research and Wellness Foundation, and a fellowship from Plan Nacional I-D+I 2008-2011 FECYT-Ministerio de Ciencia e Innovación, Spain (FCG), Swedish Research Council (GTW5343), the Swedish Diabetes Association, and the Family Ernfors Fund. The authors declare no conflicts of interest.

\section{REFERENCES}

1. Bonner-Weir, S.; Li, W. C.; Ouziel-Yahalom, L.; Guo, L.; Weir, G. C.; Sharma, A. Beta-cell growth and regeneration: Replication is only part of the story. Diabetes 59(10):2340 2348; 2010.

2. Bullwinkel, J.; Baron-Luhr, B.; Ludemann, A.; Wohlenberg, C.; Gerdes, J.; Scholzen, T. Ki-67 protein is associated with ribosomal RNA transcription in quiescent and proliferating cells. J. Cell. Physiol. 206(3):624-635; 2006.

3. Butler, A. E.; Cao-Minh, L.; Galasso, R.; Rizza, R. A.; Corradin, A.; Cobelli, C.; Butler, P. C. Adaptive changes in pancreatic beta cell fractional area and beta cell turnover in human pregnancy. Diabetologia 53(10):2167-2176; 2010.

4. Butler, A. E.; Janson, J.; Bonner-Weir, S.; Ritzel, R.; Rizza, R. A.; Butler, P. C. Beta-cell deficit and increased beta-cell apoptosis in humans with type 2 diabetes. Diabetes 52(1): 102-110; 2003.

5. Davalli, A. M.; Ogawa, Y.; Scaglia, L.; Wu, Y. J.; Hollister, J.; Bonner-Weir, S.; Weir, G. C. Function, mass, and replication of porcine and rat islets transplanted into diabetic nude mice. Diabetes 44(1):104-111; 1995.

6. Gregg, B. E.; Moore, P. C.; Demozay, D.; Hall, B. A.; Li, M.; Husain, A.; Wright, A. J.; Atkinson, M. A.; Rhodes, C. J. Formation of a human beta-cell population within pancreatic islets is set early in life. J. Clin. Endocrinol. Metab. 97(9):3197-3206; 2012.

7. Henquin, J. C.; Rahier, J. Pancreatic alpha cell mass in European subjects with type 2 diabetes. Diabetologia 54(7):1720-1725; 2011.

8. In't Veld, P.; De Munck, N.; Van Belle, K.; Buelens, N.; Ling, Z.; Weets, I.; Haentjens, P.; Pipeleers-Marichal, M.; Gorus, F.; Pipeleers, D. Beta-cell replication is increased in donor organs from young patients after prolonged life support. Diabetes 59(7):1702-1708; 2010.

9. King, A. J.; Fernandes, J. R.; Hollister-Lock, J.; Nienaber, C. E.; Bonner-Weir, S.; Weir, G. C. Normal relationship of beta- and non-beta-cells not needed for successful islet transplantation. Diabetes 56(9):2312-2318; 2007.

10. Kohler, C. U.; Kreuter, A.; Rozynkowski, M. C.; Rahmel, T.; Uhl, W.; Tannapfel, A.; Schmidt, W. E.; Meier, J. J. Validation of different replication markers for the detection of beta-cell proliferation in human pancreatic tissue. Regul. Pept. 162(1-3):115-121; 2010.

11. Kohler, C. U.; Olewinski, M.; Tannapfel, A.; Schmidt, W. E.; Fritsch, H.; Meier, J. J. Cell cycle control of beta-cell replication in the prenatal and postnatal human pancreas. Am. J. Physiol. Endocrinol. Metab. 300(1):E221-E230; 2011.

12. Kroon, E.; Martinson, L. A.; Kadoya, K.; Bang, A. G.; Kelly, O. G.; Eliazer, S.; Young, H.; Richardson, M.; Smart, N. G.; Cunningham, J. ;Agulnick, A. D.; D’ Amour, K. A.; Carpenter, M. K.; Baetge, E. E. Pancreatic endoderm derived from human embryonic stem cells generates glucose-responsive insulin-secreting cells in vivo. Nat. Biotechnol. 26(4):443-452; 2008.

13. Levitt, H. E.; Cyphert, T. J.; Pascoe, J. L.; Hollern, D. A.; Abraham, N.; Lundell, R. J.; Rosa, T.; Romano, L. C.; Zou, B.; O’Donnell, C. P. ; Stewart, A. F.; Garcia-Ocana, A.; Alonso, L. C. Glucose stimulates human beta cell replication in vivo in islets transplanted into NOD-severe combined immunodeficiency (SCID) mice. Diabetologia 54(3):572-582; 2011.

14. Menge, B. A.; Tannapfel, A.; Belyaev, O.; Drescher, R.; Muller, C.; Uhl, W.; Schmidt, W. E.; Meier, J. J. Partial pancreatectomy in adult humans does not provoke beta-cell regeneration. Diabetes 57(1):142-149; 2008.

15. Nath, D. S.; Gruessner, A. C.; Kandaswamy, R.; Gruessner, R. W.; Sutherland, D. E.; Humar, A. Outcomes of pancreas transplants for patients with type 2 diabetes mellitus. Clin. Transplant. 19(6):792-797; 2005.

16. Nir, T.; Melton, D. A.; Dor, Y. Recovery from diabetes in mice by beta cell regeneration. J. Clin. Invest. 117(9):25532561; 2007.

17. Perl, S.; Kushner, J. A.; Buchholz, B. A.; Meeker, A. K.; Stein, G. M.; Hsieh, M.; Kirby, M.; Pechhold, S.; Liu, E. H.; Harlan, D. M.; Tisdale, J. F. Significant human beta-cell turnover is limited to the first three decades of life as determined by in vivo thymidine analog incorporation and radiocarbon dating. J. Clin. Endocrinol. Metab. 95(10):E234-E239; 2010. 
18. Pisania, A.; Weir, G. C.; O’Neil, J. J.; Omer, A.; Tchipashvili, V.; Lei, J.; Colton, C. K.; Bonner-Weir, S. Quantitative analysis of cell composition and purity of human pancreatic islet preparations. Lab. Invest. 90(11):1661-1675; 2010.

19. Reers, C.; Erbel, S.; Esposito, I.; Schmied, B.; Buchler, M. W.; Nawroth, P. P.; Ritzel, R. A. Impaired islet turnover in human donor pancreata with aging. Eur. J. Endocrinol. 160(2):185-191; 2009.

20. Ricordi, C.; Lacy, P. E.; Finke, E. H.; Olack, B. J.; Scharp, D. W. Automated method for isolation of human pancreatic islets. Diabetes 37(4):413-420; 1988.

21. Ritzel, R. A.; Butler, A. E.; Rizza, R. A.; Veldhuis, J. D.; Butler, P. C. Relationship between beta-cell mass and fasting blood glucose concentration in humans. Diabetes Care 29(3):717-718; 2006.

22. Rooman, I.; Bouwens, L. Combined gastrin and epidermal growth factor treatment induces islet regeneration and restores normoglycaemia in $\mathrm{C} 57 \mathrm{~B} 16 / \mathrm{J}$ mice treated with alloxan. Diabetologia 47(2):259-265; 2004.

23. Scholzen, T.; Gerdes, J. The Ki-67 protein: From the known and the unknown. J. Cell. Physiol. 182(3):311-322; 2000.

24. Shapiro, A. M.; Ricordi, C.; Hering, B. J.; Auchincloss, H.; Lindblad, R.; Robertson, R. P.; Secchi, A.; Brendel, M. D.; Berney, T.; Brennan, D. C.; Cagliero, E.; Alejandro, R.; Ryan, E. A.; DiMercurio, B.; Morel, P.; Polonsky, K. S.; Reems, J. A.; Bretzel, R. G.; Bertuzzi, F.; Froud, T.; Kandaswamy, R.; Sutherland, D. E.; Eisenbarth, G.; Segal, M.; Preiksaitis, J.; Korbutt, G. S.; Barton, F. B.; Viviano, L.; Seyfert-Margolis, V.; Bluestone, J.; Lakey, J. R. International trial of the Edmonton protocol for islet transplantation. N. Engl. J. Med. 355(13):1318-1330; 2006.
25. Suarez-Pinzon, W. L.; Lakey, J. R.; Brand, S. J.; Rabinovitch, A. Combination therapy with epidermal growth factor and gastrin induces neogenesis of human islet $\{$ beta\}-cells from pancreatic duct cells and an increase in functional \{beta\}-cell mass. J. Clin. Endocrinol. Metab. 90(6):3401-3409; 2005.

26. Suarez-Pinzon, W. L.; Lakey, J. R.; Rabinovitch, A. Combination therapy with glucagon-like peptide-1 and gastrin induces beta-cell neogenesis from pancreatic duct cells in human islets transplanted in immunodeficient diabetic mice. Cell Transplant. 17(6):631-640; 2008.

27. Suarez-Pinzon, W. L.; Yan, Y.; Power, R.; Brand, S. J.; Rabinovitch, A. Combination therapy with epidermal growth factor and gastrin increases beta-cell mass and reverses hyperglycemia in diabetic NOD mice. Diabetes 54(9):25962601; 2005.

28. Tellez, N.; Joanny, G.; Escoriza, J.; Vilaseca, M.; Montanya, E. Gastrin treatment stimulates beta-cell regeneration and improves glucose tolerance in 95\% pancreatectomized rats. Endocrinology 152(7):2580-2588; 2011.

29. Tyrberg, B.; Ustinov, J.; Otonkoski, T.; Andersson, A. Stimulated endocrine cell proliferation and differentiation in transplanted human pancreatic islets: Effects of the ob gene and compensatory growth of the implantation organ. Diabetes 50(2):301-307; 2001.

30. Xu, G.; Stoffers, D. A.; Habener, J. F.; Bonner-Weir, S. Exendin-4 stimulates both $\beta$-cell replication and neogenesis, resulting in increased b-cell mass and improved glucose tolerance in diabetic rats. Diabetes 48:2270-2276; 1999.

31. Yatoh, S.; Dodge, R.; Akashi, T.; Omer, A.; Sharma, A.; Weir, G. C.; Bonner-Weir, S. Differentiation of affinitypurified human pancreatic duct cells to beta-cells. Diabetes 56(7):1802-1809; 2007. 